\title{
REVIEWABILITY: STATUTORY LIMITATIONS ON THE AVAILABILITY OF JUDICIAL REVIEW
}

The modern trend of the judiciary ${ }^{1}$ and the Congress ${ }^{2}$ has been toward broader review of administrative action. ${ }^{3}$ However, two recent and important pieces of environmental legislation-the Clean Air Amendments of $1970^{4}$ and the Federal Water Pollution Control Act (FWPCA) - contain unusual procedures which severely limit judicial review of administrative activities pursuant to those statutes. The literal language of the review provisions of these acts call into question any schematization of the law on reviewability and raise anew the problems of due process and judicial power. This discussion will describe the unique judicial review provisions, outline the constitutional problems they present-particularly in light of the recent interpretation given the provisions in Getty Oil Co. $v$.

1. In Barlow v. Collins, 397 U.S. 159, 166 (1970), the Court proclaimed: "Indeed, judicial review of administrative action is the rule, and nonreviewability an exception which must be demonstrated." For more enthusiastic affirmations of the presumption of reviewability, see Association of Data Processing Serv. Organizations, Inc. v. Camp, 397 U.S. 150, 156-57 (1970); Abbott Laboratories v. Gardner, 387 U.S. 136, 140 (1967).

These cases espouse the philosophy that reviewability of agency action will be presumed unless there is a clear showing of congressional intent to the contrary. But Professor Davis warns that the language in these cases must not be read literally and that lower courts have not always followed the Supreme Court proclamations. Davis \& 28.08 at 946-47 (Supp. 1970).

2. Section 10 of the Administrative Procedure Act (APA), 5 U.S.C. $\S 701$ et seq. (1970), is the most notable legislative statement on reviewability of administrative action and contains "generous review provisions." Shaughnessy v. Pedreiro, 349 U.S. 48, 51 (1955). Professor Jaffe describes the APA as "codifying the presumption of reviewability." JAFFE 372. Congress has furthered the movement toward broader reviewability on several occasions by amending statutes, which previously precluded judicial review, to make review possible. See, e.g., 50 U.S.C. $\$$ 1218(a) (1970), formerly ch. 15, § 108, 65 Stat. 21 (1951); 8 U.S.C. $\S 1105$ (a), formerly ch. 477, \$242, 66 Stat. 208-10 (1952).

3. For a discussion of the 19th century judicial deference to administrative power and the modern trend toward a presumption of reviewability, see JAFFE 33653.

4. 42 U.S.C. $\$ 1857$ et seq. (1970).

5. Pub. L. No. $92-500$ (Oct. 18, 1972), reprinted in U.S. CoDE CoNG. \& AD. News No. 10 at 4825 (1972). 
Ruckelshaus ${ }^{B}$ and suggest ways in which the courts may resolve those problems.

\section{The Review Procedures of the Clean Air Amendments and the FWPCA}

Employing identical language, section $307(\mathrm{~b})$ of the Clean Air Amendments and section 509 (b) of the FWPCA regulate in an extraordinary manner judicial review of the air and water pollution regulations and standards, which are promulgated or approved by the Environmental Protection Agency (EPA). ${ }^{7}$ Under the review procedures, a party aggrieved by EPA's promulgation of a regulation or its approval of a state standard ${ }^{8}$ has a limited period in which to file a petition for review in a federal court of appeals. ${ }^{p}$

6. 467 F.2d 349 (3d Cir. 1972), cert. denied, 41 U.S.L.W. 3392 (U.S. Jan. $16,1973)$.

7. Section 307(b) of the Clean Air Amendments, 42 U.S.C. $\$ 1857 \mathrm{~h}-5$ (1970), provides:

(1) A petition for review of action of the Administrator ... may be filed only in the United States Court[s] of Appeal .... Any such petition shall be filed within thirty days from the date of such promulgation or approval, or after such date if such petition is based solely on grounds arising after such 30th day.

(a) Action of the Administrator with respect to which review could have been obtained under paragraph (1) shall not be subject to judicial review in civil or criminal proceedings for enforcement.

Section 509(b) of the Federal Water Pollution Control Act, Pub. L. No. 92-500, $\S 509$ (b) (Oct. 18, 1972), provides:

(1) Review of the Administrator's action ... . may be had by any interested person in the Circuit Court of Appeals of the United States for the Federal judicial district in which such person resides or transacts such business upon application by such person. Any such application shall be made within ninety days of such determination, approval, promulgation, issuance or denial [being challenged], or after such date only if such application is based solely on grounds which arose after such ninetieth day.

(2) Action of the Administrator with respect to which review could have been obtained under paragraph (1) of this subsection shall not be subject to judicial review in any civil or criminal proceeding for enforcement.

It is important to note that both statutes use identical language in their second paragraph to limit review of regulations in judicial enforcement proceedings. Although different language is used, both statutes are also similar in their grant of original jurisdiction to circuit courts of appeal and in their limitation of the time period for obtaming review.

8. The statutes do not state any particular standing requirements for petitioners for review. See note 7 supra. However, in the senate report on the FWPCA, the senate committee stated that "[a]ny person has standing in court to challenge administratively developed standards, rules and regulations under the Act." S. REP. No. 414, 92d Cong., 2d Sess. 85 (1972). Presumably, this sweeping statement is limited by the constitutional requirement of case or controversy, although arguably not by the traditional judicial rules of standing. See pp. 218-52 supra.

9. Petition for review inust be filed within 30 days under the Clean Air Amend- 
If, however, a party fails to avail itself of this opportunity for review of the regulation in question within the prescribed time period, ${ }^{10}$ the regulation "shall not be subject to judicial review in civil or criminal proceedings for enforcement."11 The unusual nature of the environmental law review procedures is twofold. First, they bar collateral attack of a regulation in an enforcement proceeding in the courts which may impose serious civil and criminal sanctions; ${ }^{12}$ such a bar has not been incorporated into any najor regulatory scheme since the Emergency Price Control Act of 1942. ${ }^{13}$ Second, although placing time restrictions on review of agency orders or adjudicative decisions is not uncommon, ${ }^{14}$ it has been held that

ments, 42 U.S.C. $\$ 1857 \mathrm{~h}-5(\mathrm{~b})(1)$ (1970), and within 90 days under the FWPCA, Pub. L. No. 92-500, §509(b) (1) (Oct. 18, 1972).

10. Both statutes allow judicial review "if such petition is based solely on grounds arising" after the expiration date of the original review time period. The legislative history makes it clear that this proviso is not a general "saving clause." Rather, it is a narrow exception allowing for reconsideration of the regulation in the event of discovery of new scientific or technical data. S. REP. No. 414, 92d Cong., 2d Sess. 85 (1972); S. REP. No. 1196, 91st Cong., 2d Sess. 41-42 (1970).

11. Pub. L. No. 92-500, $\$ 509$ (b)(2) (Oct. 18, 1972); 42 U.S.C. $\S 1857 \mathrm{~h}-5$ (b) (2) (1970).

12. The Clean Air Amendments provide for a maximum $\$ 25,000$ per day fine and/or a maximum one year imprisonment, or injunctions for violation of stationary source regulations, 42 U.S.C. $\& 1857 \mathrm{c}-8$ (1970); a maximum $\$ 10,000$ fine per violation per vehicle for violations of mobile source regulations, id. § 1857f-4; and the threat of loss of certification for violation of aircraft emission regulations, id. $\S$ $1857 \mathrm{f}-10$.

The FWPCA carries a criminal penalty of a fine of $\$ 2500$ to $\$ 25,000$ per day of violation or a maximum one year imprisonment for willful violation of permit conditions or emission himitations, all penalties doubling after the first conviction, Pub. L. No. 92-500, $\$ 309$ (c) (Oct. 18, 1972). The FWPCA also provides for a civil penalty of a $\$ 10,000$ fine for permit-condition or emission-limitation violations, $i d$. $\$ 309$ (a), and for injunctive remedies, id. $\$ 309$ (b).

13. Ch. 26, $\$ 204,56$ Stat. 23 (1942). The statute gave exclusive jurisdiction to the Emergency Court of Appeals to review price regulations. Id. $\$ 204$ (a). Petitions had to be filed within 60 days of the promulgation of the regulation. Id. § 203(a). In Yakus v. United States, 321 U.S. 414 (1943), when the defendant in a criminal enforcement suit sought to challenge the validity of the regulation, the Supreme Court ruled that it was without jurisdiction to decide the matter, since the statute expressly denied jurisdiction to any other court, id. at 429-31.

The similarity between the Emergency Price Control Act and the statutes under discussion was short-lived. Upset with what it considered an unfair result in Yakus, Congress amended the price control statute to allow defendants leave to challenge the validity of a regulation by certification to the Emergency Court of Appeals, even if the 60 day time himit had run. Stabilization Extension Act of 1944, ch. 325, § 107, 58 Stat. 639 (1944), amending ch. 26, § 204, 56 Stat. 23 (1942). The arrangement was modified to 30 days under the Defense Production Act of 1950, ch. 932, \& 408(e), 64 Stat. 809-10 (1950).

14. Under many regulatory statutes, review of "agency orders" may be sought 
agency regulations-different in nature from orders and adjudicative decisions ${ }^{15}$ - should normally not be subject to the same type of time limitations. ${ }^{16}$

\section{The Legislative History}

The language of section 307(b) of the Clean Air Amendments first appeared in the conference committee bill. ${ }^{17}$ The house bill contained no provisions restricting review, ${ }^{18}$ and the senate

in a circuit court of appeals within 60 days of the issuance of the order. E.g., Federal Trade Commission Act, 15 U.S.C. \& 45(c) (1970); Securities Act of 1933, id. \$ 77(i); Securities Exchange Act of 1934, id. § 78(y); Public Utilities Holding Company Act, id. $\S 79(\mathrm{x})$; Natural Gas Act, id. $\S 717 \mathrm{r}(\mathrm{b})$; Federal Power Act, 16 U.S.C. $\$ 825(1)$ (b) (1970); Fair Labor Standards Act, 29 U.S.C. $\$ 210$ (1970); Communications Act, 47 U.S.C. $\$ 402$ (b). See also 28 U.SC. $\$ 2342$ (1970), which provides for a 60 day period to seek review of "designated orders" of the FCC, Seeretary of Agriculture, Maritime Commission, Maritime Administration, and AEC.

It must be noted, however, that many equally important regulatory statutes impose no time limit whatsoever in their review provisions. E.g., Economic Stabilization Act, Pub. L. No. 92-210, § 211 (Dec. 22, 1971). Cf. National Traffic and Motor Safety Act, 15 U.S.C. $\$ 1394$ (a)(1), (6) (1970); Food, Drug and Cosmetic Act. 21 U.S.C. \& 371(f)(1), (6) (1970); National Labor Relations Act, 29 U.S.C. $\$ 160(f)$ (1970); Civil Aeronautics Act, 49 U.S.C. $\$ 1486$ (1970).

15. The distinction between agency orders involving adjudicative determinations and agency regulations is embodied in the APA. In its section on definitions, the APA states that "rule" means "an agency statement . . . designed to implement, interpret or prescribe law . .." and that an "order" means "a final disposition . . . of an agency in a matter other than rulemaking . . . " 5 U.S.C. $\S \S 551(4)$, (6) (1970) (emphasis added). See also Davs $\$ 7.03$ at 415-20.

16. In R.A. Holman \& Co. v. SEC, 299 F.2d 127 (D.C. Cir. 1962), because the review provisions of the statute pertained to agency orders, the petitioner of an SEC rule was found not to be within the statutory review provisions and was allowed to bring his case directly under the Declaratory Judgnent Act and the APA. See also Functional Music, Inc. v. FCC, 274 F.2d 543 (D.C. Cir. 1958), cert. denied, 361 U.S. 813 (1959), where the court found the exclusive review procedure of the statute was not inandated for a plaintiff seeking review of a Commission rule. The District of Columbia Circuit elaborated on the need for differing treatment of agency orders and agency rules:

[U]nlike ordinary and adjudicatory orders, administrative rules and regulations are capable of continuing application; limiting the right of review of the underlying rule would effectively deny many parties .... an opportunity to question its validity. And see Columbia Broadcasting System v. United States, 1941, 316 U.S. 407, 421, [other citations onitted] . . , for example, where the Supreme Court clearly contemplated the continuing availability of review of Communications Commission rules and regulations. $I d$. at 546-47.

It can be seen therefore that the limiting of review of agency rules is more drastic than of agency orders, and consequently, courts have hesitated to apply to agency rules limitations referring specifically to agency orders.

17. See H. REP. No. 1783, 91st Cong., 2d Sess. 35, 57 (1970).

18. H.R. 17255, 91st Cong., 2d Sess. (1970), reprinted in H. REP. No. 1146, 
version was aimed only at preventing the stay of a regulation during the review process ${ }^{19}$ - a common statutory provision. ${ }^{20}$ However, the senate bill would have permitted a court to stay a regulation. upon a clear showing of a likelihood of success of petitioner's case on the merits and the absence of public harm. ${ }^{21}$ The turn toward the comparatively inflexible language, which was subsequently enacted as section 307 (b), is not explained in the conference committee reports. ${ }^{22}$ In adopting the same review provisions for the FWPCA, the conference committee again offered little explanation:

The conferees intend that this provision limit the availability of judicial review of a standard or requirement where judicial review was available at the time the standard or requirement was established. The conferees do not intend to, in any way, effect the right of a party for which review was not available. ${ }^{23}$

In view of the uncommon nature of these provisions, the brevity of their legislative history heightens the mystery behind Congress' decision to restrict judicial review in this matter.

\section{Judicial Interpretation of the Review Provisions}

The judicial review provision of the Clean Air Amendments was first interpreted in Getty Oil Co. v. Ruckelshaus. ${ }^{24}$ In Getty, the Court of Appeals for the Third Circuit lield that section 307 of the Clean Air Amendments provides the exclusive means of pre-enforcement review of EPA regulations. ${ }^{25}$ The issue before the court in Getty was whether an imterested party could seek pre-enforcement

91st Cong., 2d Sess. 16-50 (1970). The house bill employed the old abatement conference method of pollution regulation which called for elaborate hearings, findings of fact and abatement plans for each region where pollution has interstate effects or where the state's governor requests federal assistance in abating an intrastate pollution problem. To enforce the plans adopted in an abatement conference the government would have to go into federal court where broad review of the conference and its plan may be had by the aggrieved parties.

19. S. 4358, 91st Cong., 2 d Sess. (1970), reprinted in S. REP. No. 1196, 91st Cong., $2 d$ Sess. 68-129 (1970).

20. E.g., National Labor Relations Act, 29 U.S.C. $\$ 160(\mathrm{~g})(1970)$.

21. See S. 4358 , supra note 19.

22. See H. REP. No. 1783, supra note 17 , at 57. Nor was an explanation offered in the summary of the congressional conference agreement submitted to the Senate by Senator Muskie, the senate sponsor of the legislation. See 116 CoNG. REc. 42384-86 (1970).

23. H. REP. No. 1465, 92 d Cong., 2d Sess. 148 (1972).

24. 467 F.2d 349 (3d Cir.), affg 342 F. Supp. 1006 (D. Del. 1972), cert. denied, 41 U.S.L.W. 3392 (U.S. Jan. 16, 1973).

25. Id. at 356 . 
review in a federal district court under the Declatory Judgment Act ${ }^{20}$ and the judicial review provisions of the Administrative Procedure Act ${ }^{27}$ where the party failed to comply with section 307 .

Getty Oil Company sought to challenge a regulation affecting its affiliate but had not filed its petition in the proper court nor within the time limits prescribed by section 307 . The regulation under challenge, as drafted, ${ }^{28}$ only applied to one facility, the New Castle County power station of the Delmarva Power and Light Company, and required the power plant to begin burning low sulphur-content fuel..$^{29}$ Getty Oil Company claimed that it would suffer severe financial losses if this regulation were enforced, because the power station was a market for Getty's fluid coke fuel by-product and a source of electricity and steam to run the Getty refinery. ${ }^{30}$ Thus, when the EPA issued an enforcement order against Delmarva, Getty Oil intervened to protect this mutually convenient relationship and sought pre-enforcement review of the regulation.

Getty Oil Company challenged the regulation as arbitrary and capricious and argued that the national air quality standards had already been achieved in New Castle County, thereby making further regulation unnecessary, unmerited and unauthorized. The Third Circuit dismissed Getty's petition on procedural grounds, holding that the company had failed to follow section 307 procedure-the exclusive method by which a court could grant review of EPA regulations. ${ }^{31}$ The court found that Getty Oil's challenge could not be maintained under the Declaratory Judgment Act and the Administrative Procedure Act, without circumventing section $307 .^{32}$ Thus, in view of its failure

26. 28 U.S.C. $\$ \$ 2201-02(1970)$.

27. 5 U.S.C. $\$ \$ 701-02(1970)$.

28. The regulation applied to fuel burning equipinent located in New Castle County south of Route 40 which had a maximum rate of heat input of greater than $500,000,000$ Btu per hour. The Delmarva power station was the only facility of that size within the described area. See Getty Oil Co. (Eastern Operations), Inc. v. Ruckelshaus, 342 F. Supp. 1006, 1010 (D. Del. 1972).

29. The regulation required fuel burning equipment falling within its ambit to burn fuel containing not more than $3.5 \%$ sulphur. Id.

30. The district court noted the symbiotic relation between the Getty Oil Company refinery and the Delmarva power station which was built in conjunction with the refinery. Since the low sulphur-fuel requirements would increase the cost of production of electricity at the power station (i.e., either the fluid coke would have to be refined further or more expensive low sulphur coal would have to be procured), Getty Oil Company claimed the regulation would cost it $\$ 10,000$ per day. Id. at 1010,1012 .

31. 467 F.2d at 356.

32. Section 10 of the APA provides a right to review except where expressly 
to seek review at the appropriate time and in the appropriate court, Getty Oil was barred from raising its challenge.

The Third Circuit gave little pause to the contention that refusing review had deprived Getty Oil of due process. Getty Oil had already presented its case both in the rulemaking hearings ${ }^{33}$ and in an appeal for a variance from the state. ${ }^{34}$ However, Getty's counsel had made no judicial challenge to the state agency's promulgation of the regulation, nor to the EPA's subsequent approval of the regulation. $^{35}$ In short, although Getty Oil had both actual and constructive notice of the promulgation and EPA approval of the regulation $^{36}$ and, as a large corporation, undoubtedly had the legal and financial resources to file a timely appeal under section 307 , the company had chosen to delay its challenge.

As the first judicial interpretation of the section 307 review provisions, Getty's strict construction of the statute raises constitutional questions if followed in future cases involving different classes of petitioners. The holding in Getty is unlikely to infringe upon the due process rights of a large company actively involved in the rulemaking process. However, the same conclusion may not

precluded by statute. 5 U.S.C. $\$ 701$ et seq. (1970). The court's interpretation of section 307 as the exclusive review remedy nakes section 10 inapplicable to the Clean Air Amendments. Therefore, obtaining jurisdiction under the Declaratory Judgment Act was of no avail, since Getty Oil had no cause of action under the APA.

33. The Clean Air Amendments require hearings before emission regulations can be promulgated. 42 U.S.C. $\$ \$ 1857 \mathrm{c}-5(\mathrm{a})$, (c) (1970). Arguably, any shrinkage of due process interests caused by limitations on review after the adoption of a regulation is offset by the opportunity to be heard before its promulgation.

34. Although Getty Oil did not appeal the state agency's promulgation of the regulation, it did apply for a variance from the agency's regulation pursuant to the state pollution control statute. See 7 DeL. CODE ANN. $\$ 6007$ (1970 Supp.). The agency denied Getty Oil's application, and at the time of the filing of its suit in district court, the variance application was on appeal to the Commission. Eventually, however, Getty Oil was granted a variance until the end of 1973.

35. One may wonder whether Getty Oil had not already won its battle. While the regulation aimed at Delmarva called for fuel containing a maxinnum of $3.5 \%$ sulphur, under another regulation simultaneously adopted all smaller facilities were required to burn $1 \%$ sulphur fuel. See $342 \mathrm{~F}$. Supp. at 1010 .

36. Publication of regulations in the Federal Register, pursuant to 44 U.S.C. $\$ \S$ 1505,1507 (1970), constitutes sufficient notice to bind parties subject to the regulation regardless of actual notice. See Federal Crop Ins. Corp. v. Merrill, 332 U.S. 380, 384-85 (1947). Therefore, parties are equally bound by duly proinulgated regulations whether having constructive or actual notice. The distinction, however, demonstrates the unrealistic nature of the judicial review limitations which cut off the opportunity for judicial review to classes of petitioners having only constructive notice and therefore are unable to challenge timely the regulation. 
apply to other classes of petitioners who either lack actual notice of the promulgation of the regulation or do not have ready access to expert legal assistance. For example, an enterprise which is not a major source of pollution may not have reason to follow closely the activity of EPA or a state pollution control agency. Although such a company may have constructive notice of a duly promulgated regulation, it may not have the actual notice which would compel it to seek timely judicial rehef from a possibly unjust regulation. ${ }^{37} \mathrm{~A}$ small or medium-sized business, which is often without regular counsel to inform it of the latest relevant agency actions, is likely to have no actual notice of the regulations and, therefore, will imcur difficulties in preparing and filing a petition for review in time to meet the 30 day time limit under section 307. Finally, citizen groups also face the burden of keeping informed of agency activity and coordinating their technical and legal forces to mount a timely judicial assault on regulations they believe to be too lemient. ${ }^{88}$ For these types of petitioners, the time limitations on judicial review appear to be inequitable if the holding in Getty is strictly followed, since the petitioners would be relegated to section 307 as the only means to review regulations affecting their property, health and use or enjoyment of the environment. With respect to these petitioners, EPA regulations would in effect become imviolable and seemingly immune from attack on issues of statutory interpretation, procedural irregularities, substantial evidence, and perhaps even constitutionality. ${ }^{39}$

Moreover, in criminal and civil enforcement proceedings, the constitutional problems inherent in limited review are maguified when regulations are also insulated from collateral attack. Unlike Delmarva, many parties may first gain knowledge of a regulation when they receive an EPA enforcement order. ${ }^{40}$ By that time it would be too late to challenge the regulation under section 307 (b) (1), and section 307 (b) (2) explicitly bars reviewing the validity of the regulation in the judicial enforcement proceeding. ${ }^{41}$ If the review limitation appears unfair for purposes of pre-enforcennent review by

37. See note 36 supra.

38. For a discussion of the problems facing citizen groups wishing to challenge the environmental soundness of agency action, see Hanks \& Hanks, An Environmental Bill of Rights: The Citizen Suit and the National Environmental Policy Act of 1969, 24 RUTGERS L. REv. 230, 265-68 (1969).

39. But see notes $54-55$ infra and accompanying text.

40. See notes 36-37 supra and accompanying text.

41. See notes 7 and 11 supra and accompanying text. 
these types of petitioners, it becomes more inequitable for purposes of enforcement review. ${ }^{42}$ Furthermore, the review limitations raise a second question, one of the constitutionality of restricting judicial power-that is, can the jurisdiction of the court be invoked to enforce a regulation that it is forbidden from reviewing? Therefore, the "exclusive review procedure" interpretation in Getty and the unusual bar of review in enforcement actions certainly warrant an examination into the constitutionality of the Clean Air Amendments and the FWPCA review provisions.

\section{The Constitutional Requirements of Judicial Review}

The boundaries of the constiutional requirements of judicial review of agency action have not been clearly delineated. Legal scholars have tried to determine at least the outer perimeter of the constitutional requisites, but they are unable to cite any cases directly on point. ${ }^{43}$ After his survey of the Court's peripheral treatment of the issue in a number of unrelated cases, Professor Jaffe wrote:

We can conclude then that, when a person is the object of an administrative order which will be enforced by a writ levying upon his property or person, he is at some point entitled to a judicial test of legality. ${ }^{44}$

However, Professor Jaffe declines to offer any conclusions on the requirements for judicial review of administrative action of a less threatening nature. ${ }^{45}$ Such reservation is merited, for the courts have often refused to recognize a right to judicial review in petitions involving agency determination of benefits ${ }^{46}$ and privileges. ${ }^{47}$ The

42. If demed pre-enforcement review, affected petitioners would find it necessary to reduce their pollutants. However, if denied enforcement review, the petitioners would still find it necessary to alter their mode of operations and, as well, face the civil and criminal penalties provided by the acts."

43. 4 DAVIS $\S \S 28.18-.19 ;$ J AFFE 378-94.

44. JAFFe 384.

45. Id. 388-89. Professor Jaffe in fact makes a second conclusion-that "when the United States levies directly upon property to satisfy a tax, or takes property under claim of title, the Court will insist that the legality of its claim be open to judicial review." Id. at 388-89. But this conclusion also pertains to administrative action affecting property rights directly. Professor Jaffe qualifies carefully anything beyond these two firm conclusions as speculative and recognizes "a present inability to say what additional interests will be given the protection of judicial review." Id. at 389.

46. For example, the courts have consistently dismissed veterans'-benefits cases for lack of jurisdiction. The courts have been denied jurisdiction to review determinations on benefits made by the Administrator. 38 U.S.C. $\$ 211$ (a) (1970). For a compilation of cases thereunder, see DiSilvestro v. United States, 405 F.2d 150, 153 
underlying rationale for this refusal was summarized in United States v. Babcock, ${ }^{48}$ which stated that ". . . when the United States creates rights in individuals against itself, it is under no obligation to provide a remedy through the courts."49 Professor Davis also adopts this distinction between agency action affecting government conferred benefits and privileges and agency action affecting property rights and personal liberties in order to establish a framework for investigating the constitutional basis of reviewability. ${ }^{50} \mathrm{He}$ too perceives a greater propensity on the part of the courts to grant review when the agency action approaches that of imposing legal obligations on person and property. Absent any clear-cut cases on the legal obligation end of this benefit/obligation scale, ${ }^{51}$ however,

\section{(2d Cir. 1968).}

Courts have also adhered to statutory prohibitions of judicial review and declined to review administrative action concerning other government benefits or privileges. E.g., United States v. Babcock, 250 U.S. 328, 331 (1919) (denying review of Auditor's decision on compensatiou for loss claims under the Act of March 3, 1885, ch. 335, 23 Stat. 350 (1885) (repealed 1945), which made the Auditor's decision "final"); Fountain v. United States, 427 F.2d 759 (Ct. Cl. 1970) (holding the court precluded by a federal statute, 42 U.S.C. $\$ 1465$ (e) (1970), from reviewing the Redevelopment Loan Agency's decision on the manner of making relocation payments); Fraenkel v. United States, 320 F. Supp. 605 (S.D.N.Y. 1970) (dismissing petition for review of the Foreign Claims Settlement Commission's decision on a claim for wartime losses because the statute barred review-50 U.S.C. \& 2010 (1970). For an argument that a right to judicial review should be recognized in agency action affecting government-created benefits, see Davis, Veterans' Benefits, Judicial Review, and the constitutional Problems of "Positive" Government, 39 IND. L.J. 183 (1964).

47. However, the right-privilege distinction has been viewed with increasing disfavor for 14th Amendment equal protection purposes. See Van Alstyne, Demise of the Right-Privilege Distinction in Constitutional Law, 81 HARv. L. Rev. 1439, 1454 (1968). Furthermore, in cases involving termination of welfare payments the Court has not used a lesser standard for measuring due process rights because of the "benefit" nature of the welfare claims involved. See Goldberg v. Kelly, 397 U.S. 254 (1970); Wheeler v. Montgomery, 397 U.S. 280 (1970); King v. Smith, 392 U.S. 309 (1968). Conceivably, these developments in the areas of equal protection and due process could be carried over to the problem of preclusion of judicial review and the traditional right-benefit distinction could be abandoned.

48. 250 U.S. 328, 331 (1919); accord, Switchmen's Union v. National Mediation Bd., 320 U.S. 297 (1943).

49. 250 U.S. at 331 .

50. 4 Davs $\$ 28.19$ at 103-07.

51. Id. at 106. Professor Davis recognizes that the cases coming closest to raising the question of the constitutionality of denial of review when agency action threatens to impose legal obligations (as distinct from denying government benefits) are the draft cases, see, e.g., Estep v. United States, 327 U.S. 114 (1945); and the alien deportation cases, see, e.g., Kessler v. Streeker, 307 U.S. 22, 34 (1939). But, Professor Davis admits, "the plain fact remains that the Supreme Court has never held that denial of a limited review is a denial of due process of law." DavIs $\S 28.19$ at 106 . 
even Professor Davis must state his conclusion somewhat in the negative:

The conclusion seems to be justified that not a single case upholding unreviewability is an entirely satisfactory authority in support of an idea that due process permits denial of review of questions of law, procedure and substantial evidence when the party seeking review is resisting enforcennent of a legal obligation. ${ }^{52}$

Neither Jaffe nor Davis is satisfied with the benefit/obligation correlation as a means of expressing the due process guarantee's impact on judicial review. As both recognize, the same agency action under this analysis would be reviewable by a party against whom it may be enforced, but unreviewable by a party whom it is supposed to protect or benefit. ${ }^{53}$ A person subjected to sanctions would then have a right to judicial review of a regulation which imposed obhgations upon him, but a citizen who is supposedly benefited by the regulations would have no right to judicial review of a regulation regarded as too lax. Despite the failings of this model, however, both scholars are willing to conclude that as agency action imposes greater legal obligations on person and property, the due process requirements of a right to judicial review stiffen. ${ }^{54}$ If their conclusions are correct, the review provisions of the Clean Air Act and FWPCA may be unconstitutional in limiting review of agency action which imposes severe liabilities on personal and property rights. ${ }^{55}$

However, it must be remembered that neither statute precludes judicial review in toto, but rather, each limits the period of review to 30 and 90 days repectively. ${ }^{56}$ The question then is whether this limitation is so stringent that it unreasonably infrimges upon the due process rights outlined above. In Yakus $v$. United States, ${ }^{57}$ the

52. Davis $\S 28.19$ at 106 .

53. Professor Jaffe suggests the example of the employer and the employee, both of whom are affected by an agency decision on workmen's compensation. The employer, as the object of enforcement which would levy upon his property, would be more likely to have a right to judicial review recognized in a legal system prohibiting denial of property without due process. But simce the employee's interest in the compensation would be considered a benefit rather than a property right, he may be more easily denied review. See JAFFe 388. Professor Davis suggests the similarly unfair example of a shipper and carrier in a railroad rate case. 4 Davs $\$ 28.19$ at 106.

54. JAFFe 388-89; DAvrs $\$ 28.19$ at 106.

55. For criminal and civil sanctions accompanying pollution regulations, see note 12 supra.

56. See notes 7-11 supra.

57. 321 U.S. 414 (1944). 
Supreme Court faced a similar question in a challenge to the review procedures under the Emergency Price Control Act, ${ }^{58}$ which required all petitions for review of price regulations to be taken to the Emergency Court of Appeals within 60 days and denied any other court jurisdiction to review those regulations. ${ }^{50}$ In a criminal prosecution for a violation of price regulations, the defendants in Yakus had sought to raise the invalidity of the regulation as a defense. Since the defendants had not followed the procedure for seeking review under the Act, the trial court held that a challenge to the validity of the regulation could not be permitted in the enforcement proceeding. ${ }^{60}$ The Court acknowledged the defendants' due process rights but nevertheless affirmed the lower court decision on the grounds that the 60 day period for review before the Emergency Court of Appeals provided a reasonable opportunity for the defendants to exercise due process rights. ${ }^{61}$ In coming to this conclusion, the Court carefully noted the importance of price control in a time of total war. $^{62}$ Analogizing war to other emergency situations in which private rights must be sacrificed for the common good, ${ }^{63}$ the Court found that limiting the right to review was justifiable in hight of the compelling governmental imterests involved. Thus, to determine the constitutionality of the 30 and 90 day review limitations of the Clean Air Act and the FWPCA a similar balancing of the governmental interests and due process rights is necessary. However, while Yakus suggests the metlod of determining constitutionality, that case does not necessarily dictate the result. Its precedential value must be assessed in light of two distinguishing factors: (1) the governmental interests in Yakus involved the extraordinary concerns of a nation at war, and (2) the defendants had actual knowledge of the regulation ${ }^{64}$ but nevertheless failed to challenge during the statutory review period.

Before utilizing a balancing of interests to test for an unreasonable infringement of due process rights, consideration must be given to a parallel constitutional issue-invasion of judicial power. In his dissent in Yakus, Justice Rutledge saw the constitutional problem

\footnotetext{
58. Ch. 26, § 204, 56 Stat. 31 (1942).

59. Id. See 321 U.S. at 428.

60. See 321 U.S. at 419.

61. Id. at 435 .

62. Id. at $431-33$.

63. Id. at $442-43$.

64. Id. at 435 .
} 
with the review limitations to be equally one of unconstitutional infringement of judicial power. He wrote:

[W] henever the judicial power is called into play, it is responsible directly to the fundamental law and no other authority can intervene to force or authorize the judicial body to disregard it. The problem therefore is not solely one of individual rights or due process of law. It is equally one of the separation and independence of the powers of government and of the constitutional integrity of that judicial process . . . .65

Since Marbury v. Madison, ${ }^{86}$ it has been the duty and perogative of the judiciary to decide the final validity of laws and regulations in accordance with the Constitution. Justice Rutledge perceived that the limitation on review of regulations in the Emergency Price Control Act interfered with the judiciary's execution of this duty, and protested that:

It is one thing for Congress to withhold jurisdiction. It is entirely another to confer it and direct that it be exercised in a manner inconsistent with constitutional requirements or, what in some instances may be the same thing, without regard to them. Once it is held that Congress can require the courts criminally to enforce unconstitutional laws or statutes, including regulations, or to do so without regard for their validity, the way will have been found to circnmvent the supreme law .... . ${ }^{67}$

Having already found the review procedures to be reasonable, however, the majority in Yakus characterized the limitations as a proper regulation of the courts' jurisdiction by Congress. ${ }^{68}$ This characterization has been defended by Professor Hart, who argued that, under its constitutional power to regulate the jurisdiction of the courts, Congress may deny jurisdiction to decide an issue at one point of the judicial process so long as it grants jurisdiction at another point to hear the issue. ${ }^{69}$ In Yakus then, the denial of jurisdiction to the trial court to review the price regulation was counterbalanced by the 60 day grant of jurisdiction to the Emergency Court of Appeals. The characterization by the majority in Yakus is predicated upon a finding that the alternate period for review was reasonable. Professor Hart's model also seems premised upon that conclusion.

65. Id. at 468.

66. 5 U.S. (1 Cranch) 137 (1803).

67. 321 U.S. at 468.

68. Id. at 444 .

69. Hart, The Power of Congress to Limit the Jurisdiction of Federal Courts: An Exercise in Dialectic, 66 HARv. L. REv. 1362, 1375-79 (1953). 
If in Yakus a party had had only one day to bring his case before the Emergency Court of Appeals, the statutory review provisions might well have been deemed as an assault upon the judiciary's constitutional duties and power, since such a limitation would effectively deny jurisdiction in almost all cases.

Therefore, whether a review limitation is a proper regulation of jurisdiction or is viewed as an unconstitutional invasion of judicial power, also becomes a question of whether the limitation is considered reasonable. Since neither the Clean Air Amendments nor the FWPCA bars review completely, the constitutional questions of due process and judicial power are not presented in absolute terms, but whether the limited periods for review in the acts are reasonable in light of the competing interests involved. The governmental interest presented by the Acts is the speedy, uninterrupted admimistration of pollution control regulations to prevent degradation of the environment. ${ }^{70}$ A regulatory mechanism such as the one utilized in previous federal pollution control legislation, which called for elaborate hearings, de novo review by the courts and other due process guarantees, ${ }^{71}$ would never meet the deadlines Congress has set for achieving desired levels of air and water quality. ${ }^{72}$

70. The legislative history of both acts reveals Congress' dissatisfaction with the delay and ineffectiveness in previous federal programs for pollution control. In its report on the Clean Air Amendments, the House Committee on Interstate and Foreign Commerce stated:

The purpose of the legislation reported unanimously by your committee is to speed up, expand, and intensify the war against air pollution .... A review of achievemeuts to date, however, make abundantly clear that the strategies which we have pursued in the war against air pollution have been imadequate in several important respects, and the methods employed in implementing those strategies often have been slow and less effective than they might have been. H. REP. No. 1146, 91st Cong., 2d Sess. 1 (1970).

In approving the FWPCA, the Senate Committee on Public Works noted the inadequacy of enforcement under earlier federal water pollution regulatory schemes which brought only one case to court in two decades. In the FWPCA Congress set a goal of zero pollutant discharges into the waterways by 1985. To obtain this goal the Congress also wrote many timetables or time sequences into the Act. The Committee explamed the time limitations on judicial review as necessary "in order to maintain the time sequences provided throughout the Act." S. REP. No. 414, 92d Cong., 2d Sess. 5 (1972).

71. For a criticism of federal regulation of air pollution prior to the 1970 amendments and an account of the government's tragicomic efforts to abate pollution from a small chicken rendering plant, see J. EPosito, VANISHING AIR 114-51 (1970).

72. The Clean Air Ameudments call for achievement of the primary air quality standards (which are the level of air quality at which public health may be assured with a margin of safety) within three years of the promulgation of state reg- 
In measuring the governmental interest in meeting these deadlines, however, it must be asked whether pollution control is such a significantly pressing national need so as to justify its unusual review limitations. There are no doubts that other critical social problems exist which demand resolution through government interventionfor example, inflation, crime, food and drug quality, traffic safety, labor-management disputes. However, similar judicial review limitations have not been considered necessary despite the pressing nature of those national needs. ${ }^{73}$ In Yakus, the Court found the interest of a nation engaged in a war to be urgent enough to cut short the opportunity for judicial review. The "pollution problem" is arguably not of the maguitude as World War II. ${ }^{74}$ It also must be asked whether regulation of air and water polution involves more difficult administrative tasks which would be irreparably disrupted by judicial review, thereby justifying the stricter review limitations of the Clean Air Act and the FWPCA. It would appear that it is little more difficult administratively to regulate industrial discharges into the air and waterways than to regulate the quality of food and drugs, wage and price levels, trade practices or other subjects of governmental control. ${ }^{75}$ Finally, whether the government could

ulations. See 42 U.S.C. $\$ 1857 \mathrm{c}-5(\mathrm{a})(2)(\mathrm{A})$ (i) (1970). Since most state implementation plans were promulgated by the summer of 1972 , the target date in most instances is 1975.

The FWPCA sets a national goal of zero emission of pollutants into the waterways by 1985 . See Pub. L. No. 92-500, \& 101(a)(1) (Oct. 18, 1972).

73. As noted earlier the review limitations in the Clean Air Act and FWPCA are unusual in that they (1) impose a time limit on petitioning for review of agency regulations, as distinguished from agency orders, and (2) bar collateral attack in criminal and civil enforcement proceedings. See notes 14-16 supra and accompanying text. Cf. McAllister, Statutory Roads to Review of Federal Administrative Orders, 28 CALIF. L. Rev. 129 (1940).

74. Yakus' precedential value may be undermined by the unusual circumstances - that is, world war-in which the Emergency Price Control Act was passed and the case was decided.

75. While the FWPCA and the Clean Air Amendments apply to a great number of facilities which discharge pollutants into the air and waterways, it is not clear that the administrative task in regulating this large group is more difficult than, for example, the task given the Labor Department in administering the Occupational Safety and Health Act, 29 U.S.C. $\$ \S 651-78$ (1970), whicl covers safety conditions in 4.1 million businesses employing 57 million workers. Spann, The New Occupational Safety and Health Act, 58 A.B.A.J. 255 (1972). The Act and the regulations promulgated under it affect "virtually every employer and employee in the United States." Moran, A Critique of the Occupational Safety and Health Act of 1970, 67 Nw. U.L. Rev. 200, 202-03 (1972). See also 29 C.F.R. $§ 1975.4$ (1972). To administer the voluminous regulations applying to a wide range of working conditions, the Department of Iabor must field teams of safety imspectors 
pursue its ends through less drastic means will bear on the weight to be ascribed the government's interest in the procedure under question. As will be suggested later ${ }^{76}$ the goal of preventing delays in pollution abatement, which may cause harm to the public, could be maintained by refusing stays of the regulations or denying judicial review altogether in selected cases, rather than precluding review across the board to petitioners not qualifying under sections 307 and 509.

The due process rights of the parties affected by the regulations must be balanced against the governmental interest in uninterrupted regulation of air and water resources. Obviously, the property rights of any company using the air or waterways to dispose of industrial by-products will be affected by EPA pollution standards which require major outlays for control devices, necessitate changes in production methods, or make it impossible to remain in business. ${ }^{77}$ The impact of the regulation upon such companies will have economic repercussions for its employees, stockholders, customers and

to "constantly patrol factories, farms, and all other places of employment," maintain a staff of hearing examiners to hear challenges to citations and proposed penalties issued by the Area Directors and provide a system of appellate review. Moran, supra, at 207-10. Yet, despite the breadth of its coverage and the administrative problems inherent in such breadth, the Occupational Safety and Health Act does not contaim review himitations similar to the Clean Air Amendments and FWPCA. There is no limit on pre-enforcement review and once enforcement action is commenced a party still has an opportunity for judicial review of all issues of law, provided he raises a timely appeal. 29 U.S.C. $\$ 660$ (a) (1970). See Moran, supra, at 208-10.

Undoubtedly similar cases can be made for the administrative difficulties in other regulatory programs which affect a large number and a broad range of situations such as those under the Food, Drug and Cosmetic Act or the Economic Stabilization Act. Yet, as stated earlier, these programs also do not limit judicial review in the same drastic manner as the Clean Air Amendments and the FWPCA.

76. See notes 88-92 infra and accompanying text.

77. In Anaconda v. Ruckelshaus, 352 F. Supp. 697 (D. Colo. 1972), the district court noted the tremendous economic implications of the air pollution regulation under challenge. The regulation would have forced Anaconda to expend 60 million dollars for air pollution control equipment for its copper smelter im Montana, and, while it would have solved an air pollution problem, it could likely cause a water pollution or solid waste problem. Id. at 704 . The judge noted:

... [EPA] claim[s] an awesome power over the very life of a publicly held corporation having thousands of stockholders and employces. They claim the awesome power to destroy that corporation by virtue of a "rule" adopted at a non-adjudicatory hearing. They claim the awesome power to destroy the stockholders' investment, the frightening power to render jobless thousands of company employees, the terrifying power to destroy the economy of a state-all without an adjudicatory hearing. ld. at

Incidents of similar economic hardship caused by pollution regulations have been noted im the media. See, e.g., NEwSwEEk, Feb. 26, 1973, at 69-70. 
the community in which it is located. Furthermore, personal liberties are also potentially affected by EPA regulations since criminal sanctions are invoked in enforcement proceedings. ${ }^{78}$ Finally, to the extent that there exists a right to a clean environment and a right of a property owner to be free from the pollution of another, ${ }^{79}$ EPA's pervasive authority over the nation's air and water resources touches basic rights and interests. As suggested earlier, due process rights become increasingly necessary when important personal rights and property interests are threatened by the governmental action under question. ${ }^{80}$ Likewise, as the governmental action imposes enforcible duties upon the citizenry, the power of the judiciary to determine the validity of those duties becomes a more important check. ${ }^{81}$ Therefore, in view of the gravity of the effects of EPA action on numerous parties and interests, the due process and judicial power concerns should be weighed heavily and, absent a convincing showing of a strong contervailing state interest, could justify a holding that the present review limitations in the Clean Air Amendinents and the FWPCA are unconstitutional.

78. For a description of the civil and criminal sanctions in the Clean Air Amendments and FWPCA, see note 12 supra.

79. The discussion has centered primarily on the rights and interests of parties directly affected by EPA regulations-i.e., polluters. However, the rights and interests of many property owners and the private citizen-the non-polluters-will also be affected by EPA regulations in that the regulations establish a permissible level of pollution. If EPA becomes "captured" by the interests it is supposed to regulate or simply commits error in promulgating regulations, the "non-polluters" may seek to challenge the regulation which, in its undue permissiveness, is causing them harm. To the extent that the Clean Air Amendments and FWPCA review provisions limit the availability of review, this class of petitioners may also incur an infringement of due process rights. Arguably the infringement is not so severe or drastic as the denial of review to a party directly subject to the regulations and its sanctions. However, the rights which this class of petitioners would seek to vindicate have been recognized as important. The courts have traditionally afforded a property owner a remedy in tort for interference with the enjoyment of his property caused by the pollution of his neighbor. See, e.g., Renken v. Harvey Alumimum, Inc., 285 F.2d 321 (9th Cir.), cert. denied, 358 U.S. 840 (1958); Reynolds Metals Co. v. Yturbide, 135 F. Supp. 379 (D. Ore. 1963). See generally Juergensmeyer, Control of Air Pollution Through the Assertion of Private Rights, 1967 DURE L.J. 1126. Recently a right of every citizen to a healthful environment has been acknowledged and proclaimed. See Hanks \& Hanks, An Environmental Bill of Rights: The Citizen Suit and the National Environmental Policy Act of 1969, 24 RuTGers L. REv. 230, 244-51, 269 (1970). Therefore, denial of an opportunity to vindicate these "non-polluter" rights-which may or may not be of the same magnitude as the rights of a party forced to comply with a regulation he believes to be invalidmay still pose due process questions because of their importance.

80. See notes 43-55 supra and accompanying text.

81. See notes 65-69 supra and accompanying text. 


\section{Avoiding the Constitutional Question}

In dealing with the review provisions, however, the courts could avoid the constitutional question of due process by rendering the provisions constitutionally valid through judicial interpretation. As Professor Davis warns in his discussion of reviewability of agency action, statutory language limiting review is often not as absolute as it may literally appear. ${ }^{22}$ First, the review limitations could be avoided completely in certain cases by use of the citizen suit provisions contained in both Acts. ${ }^{83}$ Under these provisions, any citizen may bring an action in district court against the Administrator of EPA to compel him "to perforin any act or duty under this Act which is not discretionary." ${ }^{4}$ The citizen-suit provisions have already been used to order the EPA to contest procedural failings in the promulgation of regulations. ${ }^{85}$ Whether the citizen suit can be used beyond enforcing the procedural requirements of the $\operatorname{Act}^{80}$ will depend on the breadth of the interpretation given the phrase "duty under this Act which is not discretionary."

82. Davis $\$ 28.02$.

83. Federal Water Pollution Control Act, $\S 505(\mathrm{a})(2)$, Pub. L. No. $92-500$ (Oct. 18, 1972); Clean Air Amendments, 42 U.S.C. $\$ 1857 \mathrm{~h}-2$ (a) (1970).

84. Federal Water Pollution Control Act, $\$ 505(\mathrm{a})(2)$, Pub. L. No. $92-500$ (Oct. 18, 1972); Clean Air Amendments, 42 U.S.C. $\$ 1857 \mathrm{~h}-2$ (a) (1970).

85. Anaconda v. Ruckelshaus, 352 F. Supp. 697 (D. Colo. 1972). In Anaconda; the plaintiff filed his action pursuant to the citizen-suit provision. Plaintiff sought an injunction which would order the Administrator to allow cross-examination of witnesses during hearings on the state implementation plan. It must be noted, however, that in this case the regulation had not yet been promulgated. Therefore, it is not a true example of the use of the citizen-suit provision to avoid the section 307 review restrictions.

86. No intplication is intended that the procedural requirements are unimportant or de minimus. If the APA is read into the acts, it and the procedural requirements of the acts themselves confer substantial duties on the Administrator to carry out his mission in a procedurally proper manner.

87. The scope of the Administrator's "duty" may be quite broad if two recent developments involving the National Environmental Policy Act, 42 U.S.C. $\$$ 4321 et seq. (1970), are upheld. First, one court has already required EPA to file an NEPA impact statement for an air pollution regulation under challenge. Anaconda v. Ruckelshaus, 352 F. Supp. 697 (D. Colo. 1972). For a discussion of whether EPA can be required generally to file environmental impact statements under NEPA for its "federal activity" im administering the Clean Air Act, see pp. 347-58 infra. Second, there is an argument that NEPA impact statements may occasion substantive judicial review of the administrative decision they support. See pp. 301-17 infra. If then, the Administrator can be charged with a "duty" of filing an impact statement for regulations he promulgates and if, in challenging his performance of that duty, substantive review of the regulation can be had, the citizen suit could be utilized broadly to challenge regulations without time limitations on filing 
As a second alternative, the courts could decline to follow the strict interpretation in Getty of section 307 as the exclusive means of review. ${ }^{88}$ The review provisions in both Acts only contain express prohibitions of review in the criminal or civil enforcennent proceeding. ${ }^{89}$ Arguably, review could be allowed under certain conditions in other kinds of proceedings. Precedent for this type of distinction exists in Abbott Laboratories $v$. Gardner, ${ }^{90}$ where the Supreme Court held that procedures for review for one purpose should not be presumed to apply to review for other purposes. The petitioners in Abbott Laboratories sought pre-enforcement review of an agency regulation, despite their failure to follow the statutory procedures for review of agency orders. ${ }^{91}$ The court found those procedures to apply only to review of agency orders, and not to be the exclusive review procedure for all challenges to agency action. As noted earlier, the legislative history surrounding the senate version of the Clean Air Amendments reveals that the primary concern was to prevent stays of the regulations during the review process, when such stays might cause harm to the public and when the petitioner's case may be meritless or simply dilatory. ${ }^{22}$ Adopting this legislative history as representative of Congress' intent and following the distinction made in Abbott Laboratories, a court could allow review in pre-enforcement cases, but grant a stay of the regulation during

for review. However, it must be noted that this possible detour of the statutory review procedures will not work under the FWPCA, since it is expressly exempted from NEPA requirements. See Pub. L. No. 92-500 (Oct. 18, 1972). Nor does this tactic solve the problem of the defendant in an enforcement proceeding for whom the Cleau Air Amendment and FWPCA bar review.

The interpretation of the phrase "duty under this Act which is not discretionary" will also entail a consideration of the common-law remedy of mandamus. The courts will have to decide whether the phrase is simply a codification of the mandamus remedy or whether Congress intended to add to that which was already available at conmou law. Assuming arguendo that the court finds the phrase to be a statutory embodiment of common-law mandamus requirements, the scope of review may still be broad in light of the recent trend of courts to inquire into the permissible range of discretion. For a discussion of the courts' reviewing adininistrative action to determine whether it falls within the permissible scope of discretion and thereby whether inandamus will lie, see pp. 207-17 infra.

88. Perhaps Getty could be limited to its facts-a case in which a party with actual notice of the regulation and a history of participation in its promulgation failed to seek timely review. See notes 33-36 supra and accompanying text. Thus, since the constitutional question was not ripe in Getty, the case can be distinguished.

89. See notes 7 and 11 supra and accompanying text.

90. 387 U.S. 136 (1967).

91. Id. at 139. See Food, Drug and Cosinetic Act, 21 U.S.C. $\$ \S 371(f)(1)$, (6) (1970).

92. See note 19 supra and accompanying text. 
review only upon a clear showing of the petitioner's likelihood of success on the merits, irreparable injury, and the absence of significant harm to the public.

Finally, the review provisions could be interpreted as containing implied conditions or exceptions. The review sections of the Clean Air Amendinents and FWPCA simply provide that issues not reviewed in accordance with their procedures "shall not be subject to judicial review in civil or criminal proceedings for enforceinent." 93 The courts have interpreted similar language in other statutes as not precluding review for all issues or under all circumstances. For example, statutory provisions declaring that certain adıninistrative determinations "shall not be reviewed or redetermined by any court" have been reduced to merely a prohibition against review of very limited findings of fact. ${ }^{94}$ Although statutes have often provided that the decision of the Administrator or Secretary "shall be final," the courts have ordinarily interpreted "final" as not meaning final for purposes of judicial review and have granted review. ${ }^{95}$ Similarly, the courts have upheld limitations on review except for questions of "interpretation and constitutionality," or unless the action was beyond the agency's jurisdiction, ${ }^{97}$ or except for enforcennent of due process requirements. ${ }^{98}$ Indeed, Davis finds judicial writing to be so loose and filled with conditional language that he announces, tongue-in-cheek, that dictun in two Supreme

93. Pub. L. No. $92-500$, § 509(b)(2) (Oct. 18, 1972); 42 U.S.C. § 1857h.5 (b)(2) (1970).

94. The court has interpreted a seemingly sweeping limitation of judicial review in the Renegotiation Act, 65 Stat. 21 (1951), as amended, 50 U.S.C. $\$ 1218$ (a) (1970), as a denial of review only to the limited finding of the amount of profit in the government contract. United States v. California Eastern Line, Inc., 348 U.S 351 (1955).

95. The demise of the finality provision as a bar to review has come about most strikingly in two major lines of cases-the draft cases, and the alien exclusion and deportation cases. For the Court's interpretation of the finality clause in the selective service acts as not barring judicial review, see Oestercich v. Selective Serv. Sys., Local Bd. No. 11, 393 U.S. 233 (1968); Estep v. United States, 327 U.S. 114 (1945). See also Davis \& 28.12. For the Court's similar treatment of finality provisions in immigration and naturalization laws, see Brownell v. Tom We Shung, 352 U.S. 180 (1956); Shaughnessy v. Pedreiro, 349 U.S. 48 (1955). See also DAvis $\S 28.10$.

96. See Ludecke v. Watkins, 335 U.S. 160 (1948); Knu-Vise, Inc. v. War Contracts Price Adjustment Bd., 195 F.2d 198 (D.C. Cir. 1952); United States Elec. Motors, Inc. v. Jones, 153 F.2d 134 (D.C. Cir. 1946).

97. See Washington Terminal Co. v. Boswell, 124 F.2d 235 (D.C. Cir. 1941), aff'd, 319 U.S. 732 (1942). See also Davis § 28.02.

98. See Heikkila v. Barber, 345 U.S. 229, 236 (1953). 
Court decisions read together would allow the courts to "review all questions without determining whether they are reviewable." short, the court could apply any number of judicial exceptions or conditions to the review provisions to render them ineffective to one degree or another.

Unfortunately, the judiciary's history of avoiding the constitutional questions has left the subject of reviewability of agency action in disarray. The hesitancy with which the field's leading scholars address the issue of reviewability and its constitutional boundaries points up the absence of consistent judicial approaches to the problem. As a result, the treatment any review provision will receive is unpredictable, and perhaps more influenced by judicial whim than by any doctrine of law. After reviewing the judicial gymnastics engaged in by the courts in interpreting the selective service acts as permitting review, Davis queries:

. . . one may wonder whether the court would have been on sounder ground if it had interpreted "final" to mean final and then faced the problem of whether and to what extent the Constitution permits such finality. 100

Hopefully, in interpreting the review provisions of the Clean Air Act and the FWPCA, the court will choose the "sounder ground" and lay down clear constitutional guildelines for the legislature and future courts.

\section{Summary}

The two acts provide occasion for decisive judicial action. In an unusual inanner, they limit judicial review arguably to the point of effective denial of review for large classes of petitioners. Moreover, they would deny review in criminal and civil enforcement proceedings. In light of the serious impositions the unreviewable regulations would place on property rights and health, the provisions limiting review appear to be in violation of the constitutional guar-

99. Davis $\$ 28.02$ at 8 . Professor Davis notes the Court's comment in Inland Einpire Dist. Council v. Millis, 325 U.S. 697, 700 (1945), that " it would be inappropriate ... to determine the question of reviewability' unless the Board's action was unlawful" and then compares with it the Court's statement in Elgin, J. \& E.R. Co. v. Burley, 325 U.S. 711, 720 (1945) that "it will not determine the question of reviewability unless the administrative action was 'validly made." Depending on the circumstances, a conrt could invoke either the dictum in Inland or Elgin and consistently avoid the question of reviewability.

100. Davs $\$ 28.12$ at 63 . 
antee of due process. The immunization of agency action from challenge of the agency's imterpretation of the law, procedural irregularities, arbitrariness or substantial evidence- particularly immunization of agency action having such great economic repercussions as control of the nation's air and water resources-should be dealt with in constitutional terms, and a careful balancing should be made of the due process rights of those affected and the countervailing government interests. 